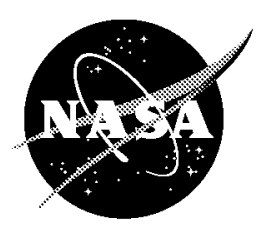

\title{
Performance of High-Frequency High-Flux Magnetic Cores at Cryogenic Temperatures
}

Scott S. Gerber

ZIN Technologies, Inc, Brook Park, Ohio

Ahmad Hammoud

QSS Group, Inc., Cleveland, Ohio

Malik E. Elbuluk

University of Akron, Akron, Ohio

Richard L. Patterson

Glenn Research Center, Cleveland, Ohio 
Since its founding, NASA has been dedicated to the advancement of aeronautics and space science. The NASA Scientific and Technical Information (STI) Program Office plays a key part in helping NASA maintain this important role.

The NASA STI Program Office is operated by Langley Research Center, the Lead Center for NASA's scientific and technical information. The NASA STI Program Office provides access to the NASA STI Database, the largest collection of aeronautical and space science STI in the world. The Program Office is also NASA's institutional mechanism for disseminating the results of its research and development activities. These results are published by NASA in the NASA STI Report Series, which includes the following report types:

- TECHNICAL PUBLICATION. Reports of completed research or a major significant phase of research that present the results of NASA programs and include extensive data or theoretical analysis. Includes compilations of significant scientific and technical data and information deemed to be of continuing reference value. NASA's counterpart of peerreviewed formal professional papers but has less stringent limitations on manuscript length and extent of graphic presentations.

- TECHNICAL MEMORANDUM. Scientific and technical findings that are preliminary or of specialized interest, e.g., quick release reports, working papers, and bibliographies that contain minimal annotation. Does not contain extensive analysis.

- CONTRACTOR REPORT. Scientific and technical findings by NASA-sponsored contractors and grantees.
- CONFERENCE PUBLICATION. Collected papers from scientific and technical conferences, symposia, seminars, or other meetings sponsored or cosponsored by NASA.

- SPECIAL PUBLICATION. Scientific, technical, or historical information from NASA programs, projects, and missions, often concerned with subjects having substantial public interest.

- TECHNICAL TRANSLATION. Englishlanguage translations of foreign scientific and technical material pertinent to NASA's mission.

Specialized services that complement the STI Program Office's diverse offerings include creating custom thesauri, building customized databases, organizing and publishing research results ... even providing videos.

For more information about the NASA STI Program Office, see the following:

- Access the NASA STI Program Home Page at http://wwzo.sti.nasa.gov

- E-mail your question via the Internet to help@stinasa.gov

- Fax your question to the NASA Access Help Desk at 301-621-0134

- Telephone the NASA Access Help Desk at 301-621-0390

- Write to: NASA Access Help Desk NASA Center for AeroSpace Information 7121 Standard Drive Hanover, MD 21076 


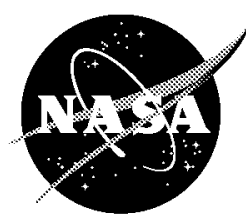

\section{Performance of High-Frequency High-Flux Magnetic Cores at Cryogenic Temperatures}

Scott S. Gerber

ZIN Technologies, Inc., Brook Park, Ohio

Ahmad Hammoud

QSS Group, Inc., Cleveland, Ohio

Malik E. Elbuluk

University of Akron, Akron, Ohio

Richard L. Patterson

Glenn Research Center, Cleveland, Ohio

Prepared for the

37 th Intersociety Energy Conversion Engineering Conference

sponsored by the Institute of Electrical and Electronics Engineers, Electron Devices Society

Washington, DC, July 28-August 2, 2002

National Aeronautics and

Space Administration

Glenn Research Center 


\section{Acknowledgments}

This work is supported by the NASA Glenn Research Center GESS Contract NAS3-00145.

The authors acknowledge Magnetics, Inc for providing samples of the cores.

Trade names or manufacturers' names are used in this report for identification only. This usage does not constitute an official endorsement, either expressed or implied, by the National Aeronautics and Space Administration.

Available from

NASA Center for Aerospace Information 7121 Standard Drive

Hanover, MD 21076
National Technical Information Service 5285 Port Royal Road Springfield, VA 22100

Available electronically at http://gltrs.grcnasa.gov 


\title{
PERFORMANCE OF HIGH-FREQUENCY HIGH-FLUX MAGNETIC CORES AT CRYOGENIC TEMPERATURES
}

\author{
Scott S. Gerber \\ ZIN Technologies, Inc. \\ Brook Park, Ohio 44142 \\ E-mail: scotts aeberogromesa cov \\ Ahmad Hammoud \\ QSS Group, Inc. \\ Cleveland, Ohio 44135 \\ E-mail: ahmad hammoudouronasa oov \\ Malik E. Elbuluk \\ University of Akron \\ Akron, Ohio 44325 \\ E-mail: melbuluk ouakron edu \\ Richard L. Patterson \\ National Aeronautics and Space Administration \\ Glenn Research Center \\ Cleveland, Ohio 44135 \\ E-mail: richard. patfersongromasa ooy
}

\begin{abstract}
Three magnetic powder cores and one ferrite core, which are commonly used in inductor and transformer design for switch mode power supplies, were selected for investigation at cryogenic temperatures. The powder cores are Molypermalloy Core (MPC), High Flux Core (HFC), and Kool Mu Core (KMC). The performance of four inductors utilizing these cores has been evaluated as a function of temperature from $20^{\circ} \mathrm{C}$ to $-180^{\circ} \mathrm{C}$. All cores were wound with the same wire type and gauge to obtain equal values of inductance at room temperature. Each inductor was evaluated in terms of its inductance, quality $(Q)$ factor, resistance, and dynamic hysteresis characteristics (B-H loop) as a function of temperature and frequency. Both sinusoidal and square wave excitations were used in these investigations. Measured data obtained on the inductance showed that both the MPC and the HFC cores maintain a constant inductance value, whereas with the KMC and ferrite core hold a steady value in inductance with frequency but decrease as temperature is decreased. All cores exhibited dependency, with varying degrees, in their quality factor and resistance on test frequency and temperature. Except for the ferrite, all cores exhibited good stability in the investigated properties with temperature as well as frequency. Details of the experimental procedures and test results are presented and discussed in the paper.
\end{abstract}

\section{INTRODUCTION}

Many deep space missions require power electronic components and systems that can operate reliably and efficiently in cryogenic temperature environments. Presently, spacecraft operating in the cold environment of deep space carry on-board a large number of radioisotope heating units (RHUs) to maintain an operating temperature for the electronics of approximately $20^{\circ} \mathrm{C}$ [1]. This is not an ideal solution because the RHUs are always producing heat, even when the spacecraft is already too hot, thus requiring an active thermal control system for the spacecraft. In addition, they are very expensive and require elaborate containment structures. Therefore, electronics capable of operation at cryogenic temperatures will not only tolerate the hostile environment of deep space but also reduce system size and weight by eliminating radioisotope heating units and associated structures; thereby reducing system development and launch costs, improving reliability and lifetime, and increasing energy densities.

Most aerospace power management systems are DC-based. To supply loads at different voltage and power levels, switching regulators represent a viable class of power electronics circuits that convert unregulated DC input voltages into regulated DC outputs. The design of these converters to operate at cryogenic temperatures is expected to result in more efficient systems than room temperature systems. This improvement requires from better electronic switches and filter components that can operate at low temperatures [2].

A typical switching power converter consists of components such as switches (transistors and diodes), transformers, inductors and capacitors for filtering. These components are designed to operate at frequency that ranges from a few $\mathrm{kHz}$ to several $\mathrm{MHz}$ and at power levels that range from a few $\mathrm{mWs}$ to MWs. Inductors represent a key element in the design and operation of such regulators as they play an important role in the filter design to achieve the required level of power quality at both input and output terminals. 
The core losses of amorphous and ferrite cores as a function of temperature were investigated in the temperature range of $-150{ }^{\circ} \mathrm{C}$ to $150{ }^{\circ} \mathrm{C}$ [3-4]. The performance of MPC and high temperature superconducting (HTS) inductor in a boost converter was evaluated at cryogenic temperatures [5].

Magnetic powder cores are known to be an ideal choice for use in the design of inductors and transformers in switch-mode power supplies due to their low loss and high Q-factor. These powder cores, such as MPC, High Flux, and Kool Mu, offer soft saturation, high magnetic flux density ( $\left.B_{\max }\right)$ and excellent temperature stability [3-5]. Molypermalloy (MPC) powder cores can be manufactured with different permeability and varying core sizes. Inductors designed with this family of cores can operate in a temperature range between $-65^{\circ} \mathrm{C}$ and $125^{\circ} \mathrm{C}$ with variation in their inductance value limited to less than 10\% [6].

High Flux powder cores have higher energy storage capacity than MPC and Kool Mu cores. They are very close to MPC in terms of permeability and core size, and are commonly used in inductors, in-line noise filters, pulse transformers, and flyback transformers [7].

Kool Mu powder cores are distributed air gap cores formulated for low loss, high frequency applications or for extremely low magnetostriction power applications, such as in energy storage filter inductor in switch-mode power supplies. These cores also come in different permeability and sizes and are economically priced between MPC cores and ferrite cores [8].

Ferrite cores exhibit low loss characteristics and are designed to operate in the temperature range of $-30{ }^{\circ} \mathrm{C}$ to $70{ }^{\circ} \mathrm{C}$. They possess high permeability from 750 to 2000 and are ideal for high-frequency $(20 \mathrm{kHz}$ to $3 \mathrm{MHz}$ ) power supplies applications. Ferrite cores can be un-gapped or gapped for saturating or nonsaturating modes for both inductor and transformer designs [9].

In this work, a ferrite core and three powder cores consisting of Molypermalloy (MPC), High Flux Core (HFC), and Kool Mu Core (KMC) were selected for characterization for potential use in extreme temperature environments. Some of the properties of these cores are listed in Table I [6-9]. Four inductors were designed using these four toroidal-shaped cores for evaluation under cryogenic conditions. All cores were wound with the same wire type and gauge to give equal values of inductance at room temperature. Measurements of each core inductance, Q-factor, resistance, and dynamic hysteresis-loop as a function of temperature were obtained in the frequency range from $1 \mathrm{kHz}$ to $200 \mathrm{kHz}$. The test temperature ranged from $20{ }^{\circ} \mathrm{C}$ to $-180{ }^{\circ} \mathrm{C}$. The desired test temperature was obtained using a Sun Systems environmental chamber utilizing liquid nitrogen as the coolant. A temperature rate of change of $10{ }^{\circ} \mathrm{C} / \mathrm{min}$ was used throughout this work. At every test temperature, the device under test was allowed to soak at that temperature for a period of 30 minutes before any measurements were made. After the last measurement was taken at $-180{ }^{\circ} \mathrm{C}$, the cores were allowed to stabilize to room temperature and then the measurements were repeated to determine if the thermal cycling had produced any effect on their operational characteristics.

\section{RESULTS AND DISCUSSIONS}

The inductance of the four cores as a function of frequency and temperature is shown in Figure 1. It can be clearly seen that all cores, at any given temperature, exhibit steady inductance value with increase in frequency up to $100 \mathrm{kHz}$. At the highest test frequency of $200 \mathrm{kHz}$, however, the ferrite core declines slightly while the other three cores undergo slight increase. In terms of temperature, the MPC and the High Flux cores do not exhibit much variation in their inductance between $25^{\circ} \mathrm{C}$ and $-190^{\circ} \mathrm{C}$. The ferrite and the Kool Mu cores, on the other hand, suffer a reduction in their inductance as temperature is decreased. These temperature-induced changes are evident at every test frequency.

TABLE I. PROPERTIES OF MAGNETIC CORES [3-6].

\begin{tabular}{|c|c|c|c|c|c|}
\hline Core & $\begin{array}{c}\text { Outer } \\
\text { Dia. } \\
\text { (in.) }\end{array}$ & $\begin{array}{c}\text { Inner } \\
\text { Dia. } \\
\text { (in.) }\end{array}$ & $\begin{array}{c}\text { Height } \\
\text { (in.) }\end{array}$ & $\begin{array}{c}\text { Temp } \\
\left({ }^{\circ} \mathrm{C}\right)\end{array}$ & $\mu_{\mathbf{r}}$ \\
\hline MPC & 1.06 & 0.58 & 0.44 & -65 to 125 & 125 \\
\hline KMC & 1.06 & 0.58 & 0.44 & -65 to 125 & 125 \\
\hline HFC & 1.06 & 0.58 & 0.44 & -65 to 125 & 125 \\
\hline Ferrite & 0.88 & 0.58 & 0.22 & -30 to 70 & 900 \\
\hline
\end{tabular}

With the exception of the ferrite core, all cores display typical characteristics in their quality factor with frequency as shown in Figure 2. The MPC, High Flux, and the Kool Mu cores attain a peak value in their $\mathrm{Q}$ factor between 80 and 180 in the vicinity of a frequency of $10 \mathrm{kHz}$. This peak, however, shifts toward lower frequency as test temperature is decreased. The ferrite core, on the other hand, exhibits inconsistent behavior in its Q-factor with frequency as shown in Figure 2. While it initially increases with frequency up to $10 \mathrm{kHz}$, the quality factor begins to decline, remains steady, or increases afterwards. These trends in the variation of the quality factor at frequencies above $10 \mathrm{kHz}$ seem to be dependent on the test temperature. At 25 and $-50{ }^{\circ} \mathrm{C}$, for example, the Q-factor increases with increase in frequency, while the opposite holds true at 100 and $-150^{\circ} \mathrm{C}$. At temperature of $-190^{\circ} \mathrm{C}$, the ferrite core maintains a relatively steady value in its quality factor throughout the entire frequency range.

Figure 3 depicts the resistance of the cores as a function of frequency at various temperatures. All cores exhibit similar trend in this property with both test parameters. It can be clearly seen that while the resistance of any of these cores remain unaffected with frequency up to $100 \mathrm{kHz}$, it dramatically increases as the frequency is increased further. This is due to the fact that the ac core and wiring losses portion of the inductor resistance become more dominant at high frequencies. The effect of temperature is more noticeable in the flat region where the resistance, as 
expected, drops down in value with a decrease in temperature.

The inductor response to a $100 \mathrm{kHz}$ square wave input excitation is shown in Figure 4 for all four cores at $25^{\circ} \mathrm{C}$ and at $-180^{\circ} \mathrm{C}$. While not much variation is observed in the response behavior of the MPC, HFC, and $\mathrm{KMC}$ cores at the two different test temperatures, the ferrite core exhibits a significant increase in the intensity level associated with a mild saturation-like distortion in its inductor current at the extreme temperature of $-180^{\circ} \mathrm{C}$. The loss of the inductance of this core, as was shown in Figure 1, is largely responsible for the increase in this inductor current.

The dynamic hysteresis characteristics of the tested cores are displayed in Figure 5 at room temperature as well as $-180^{\circ} \mathrm{C}$. These characteristics, which are represented by the $\mathrm{B}-\mathrm{H}$ loops, are indicative of the core loss of the magnetic materials. These loops are obtained by integrating the coil voltage and plotting it against its excitation current. It can be seen that the ferrite core, unlike the other three cores, exhibits a great dependency in its loss characteristics on temperature. A drastic increase in core loss, i.e., widening of the B-H loop, occurs at the extreme temperature of $-180{ }^{\circ} \mathrm{C}$ for this type of magnetic material.

\section{CONCLUSION}

Four different types of magnetic cores were investigated for potential use in cryogenic applications. These cores consisted of a ferrite and three powderbased cores. The powder cores were Molypermalloy (MPC), High Flux (HFC), and Kool Mu (KMC). The performance of four inductors utilizing these cores has been evaluated as a function of temperature from $20^{\circ} \mathrm{C}$ to $-180^{\circ} \mathrm{C}$. Each inductor was evaluated in terms of its inductance, quality $(Q)$ factor, resistance, and dynamic hysteresis characteristics (B-H loop) as a function of temperature and frequency. The results obtained on the inductance showed that both the MPC and the HFC cores maintain a constant inductance value, whereas the KMC and Ferrite hold steady values in inductance with frequency but decrease as temperature is decreased. All cores exhibit dependency, with varying degrees, in their quality factor and resistance on test frequency and temperature. Except for the ferrite, all cores exhibited good stability in the investigated properties with temperature as well as frequency. Further and more comprehensive testing is, however, required to access performance of these cores under long-term exposure to low temperature.

\section{REFERENCES}

1. R.L. Patterson, A. Hammoud, J.E. Dickman, S.S. Gerber and E. Overton, "Development of Electronics for Low Temperature Space Missions," $4^{\text {th }}$ European Workshop on Low Temperature Electronics, Noordwijk, The Netherlands, June 21-23, 2000.

2. J.M. Niedra, "Comparative Wide Temperature Core Loss Characteristics of Two Candidate Ferrites for the NASA/TRW 1500 W PEBB Converter," NASA/CR-1999209302, August 1999

3. J.M. Niedra, G.E. Schwarze, "Wide Temperature Core Loss Characteristics of Magnetically Annealed Amorphous Tapes for High Frequency Aerospace Magnetics," NASA/TM-1999-209297, August 1999.

4. Kirschman, R.K., "Cold Electronics: An Overview," Cryogenics, Vol. 25, No. 3, 1985, pp. 115-122.

5. Ray, B., Gerber, S.S., Patterson, R.L. and Dickman, J., "Low Temperature Performance of a Boost Converter with MPP and HTS Inductor," IEEE APEC 96 Conference, Vol. 2, 1996, pp. 883-888.

6. "Molypermalloy Powder Cores," Magnetics, Inc., Brochure MPC-1.05H.

7. "High Flux Powder Cores," Magnetics, Inc., Brochure $\mathrm{HFC}-1.111 \mathrm{H}$

8. "Kool Mu Powder Cores," Magnetics, Inc., Brochure KMC-2.3 3J.

9. "Ferrite Cores," Magnetics, Inc., Brochure FC-601-11H. 

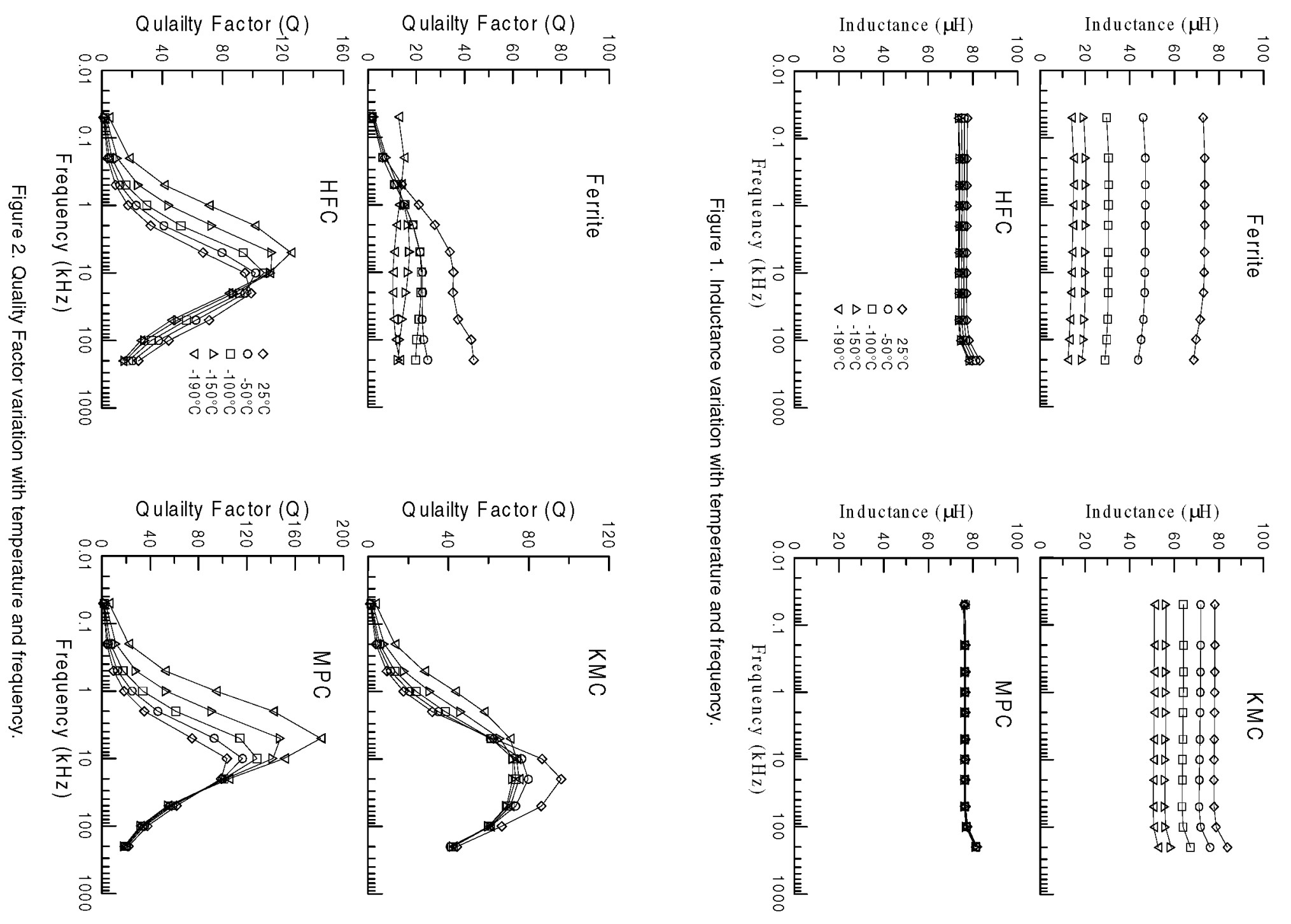

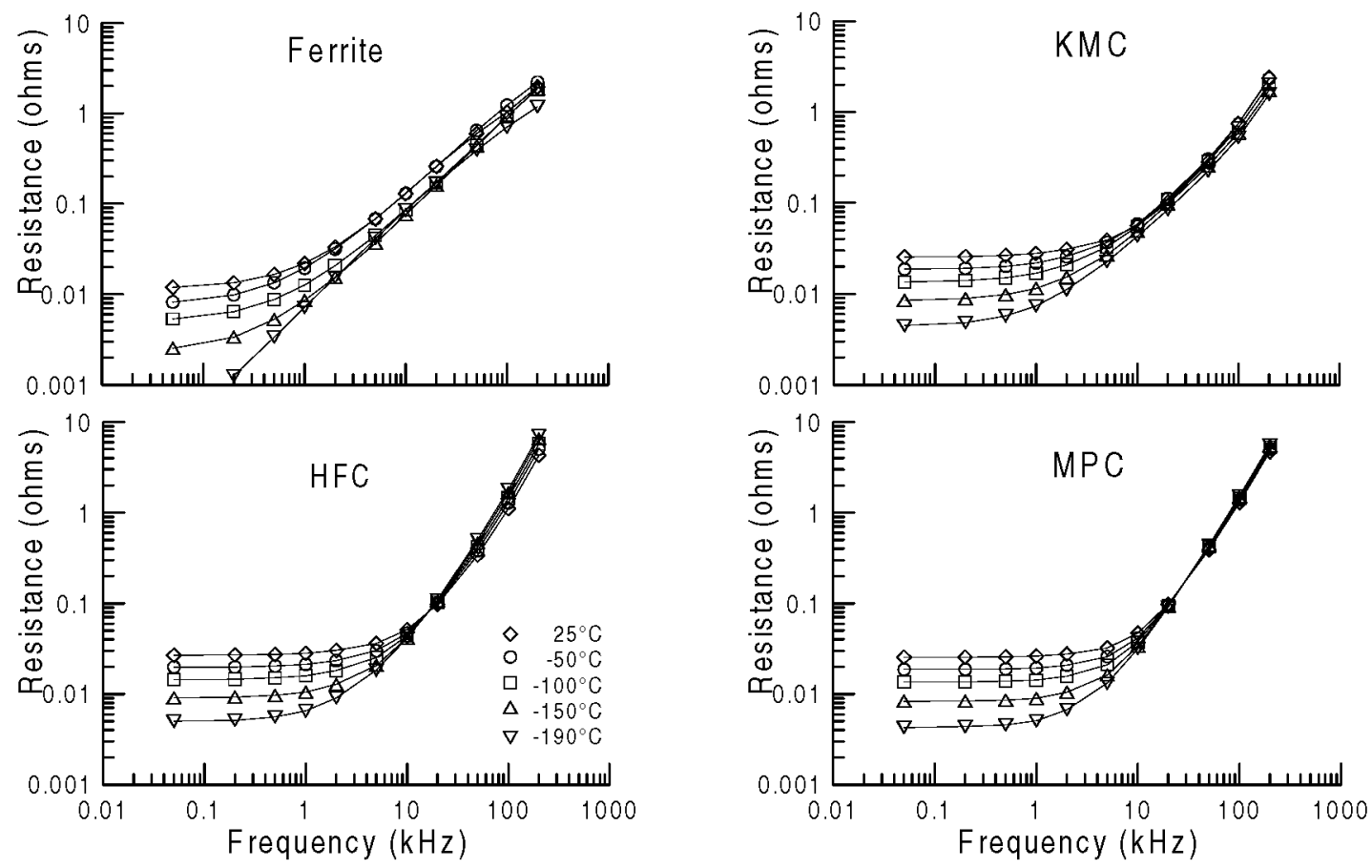

Figure 3. Resistance variation with temperature and frequency. 

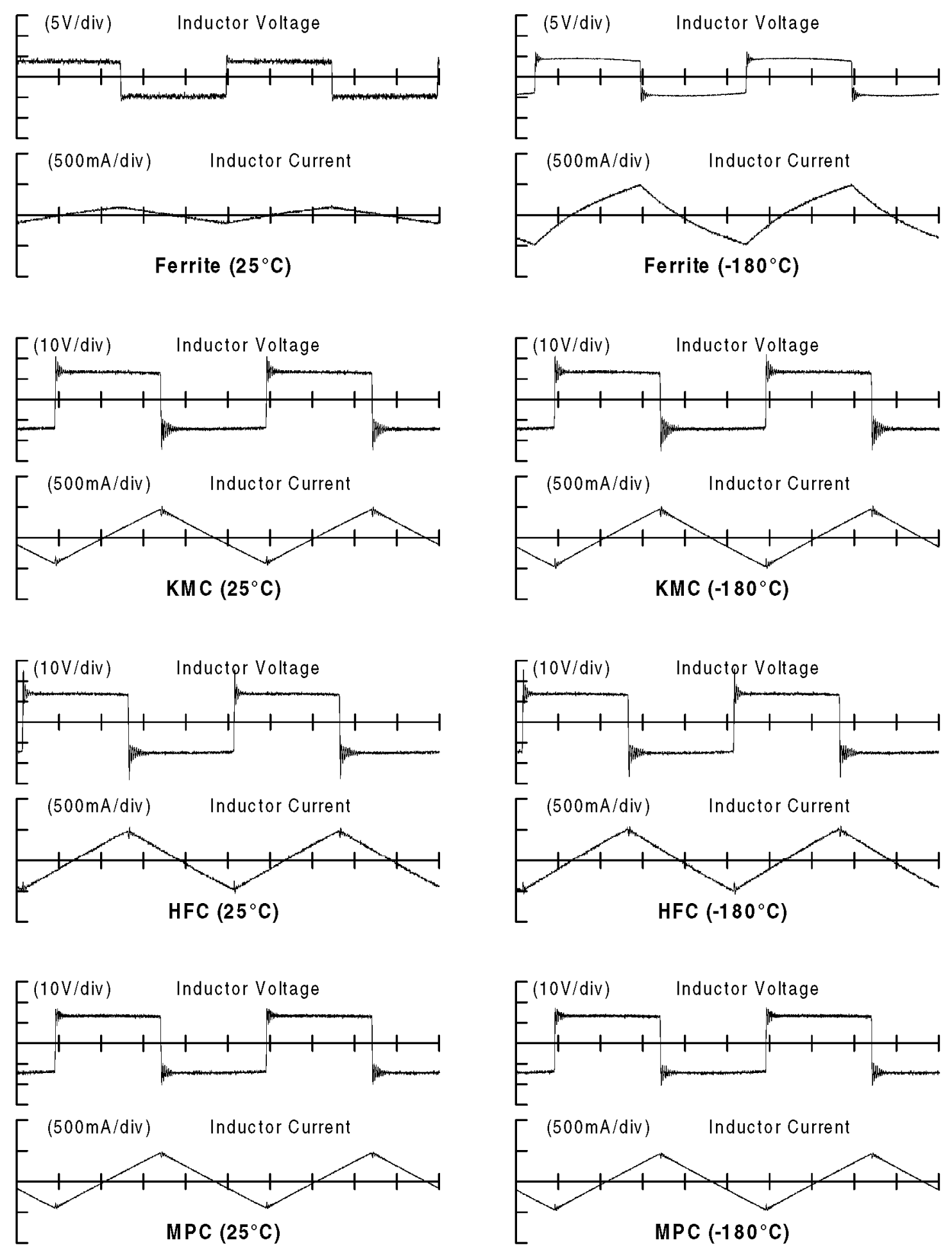

Figure 4. Response of inductors to a $100 \mathrm{kHz}$ square wave excitation. 


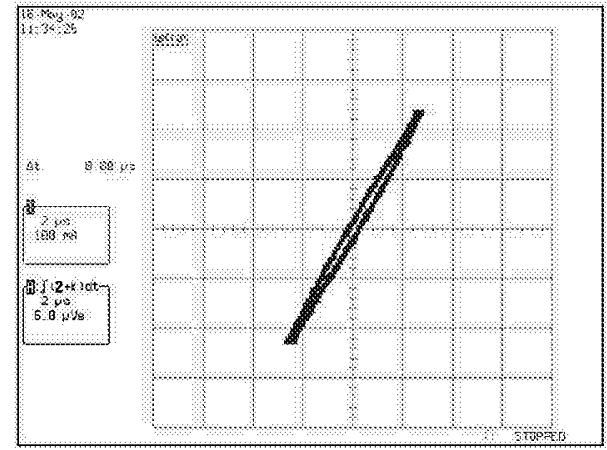

Ferrite $\left(25^{\circ} \mathrm{C}\right)$

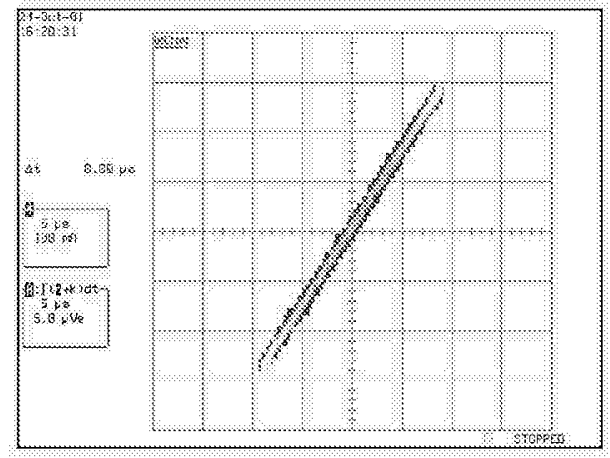

KMC $\left(25^{\circ} \mathrm{C}\right)$

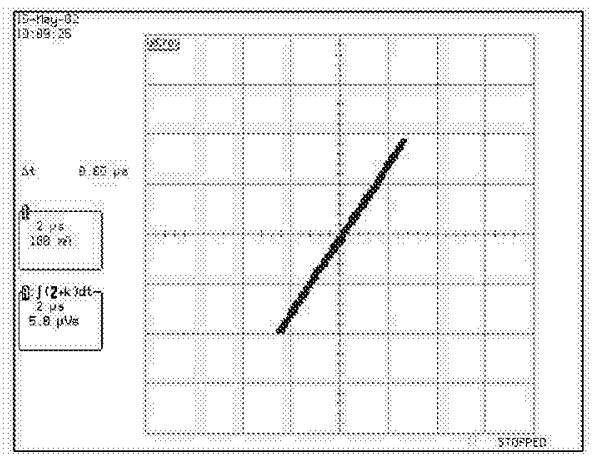

HFC $\left(25^{\circ} \mathrm{C}\right)$

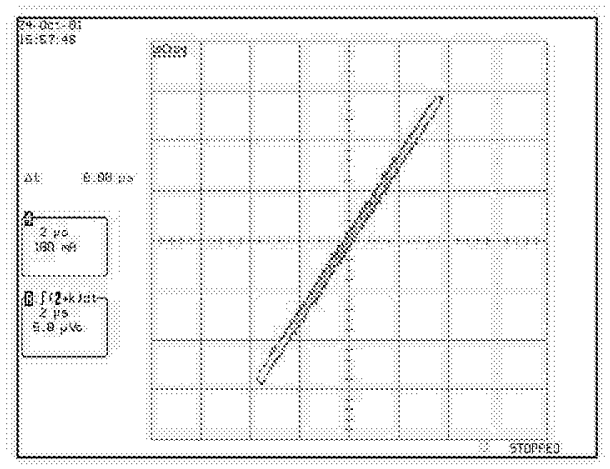

$M P C\left(25^{\circ} \mathrm{C}\right)$

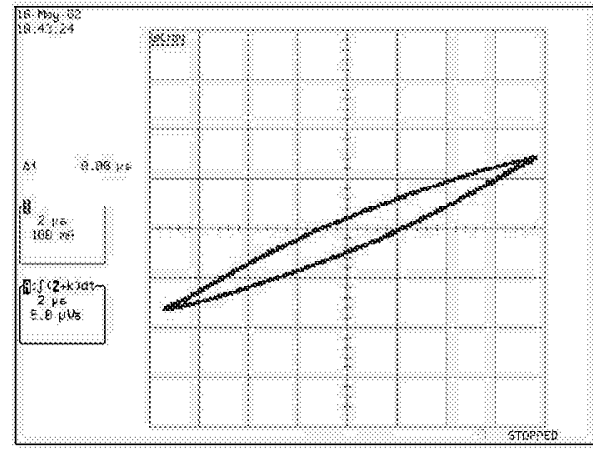

Ferrite $\left(-180^{\circ} \mathrm{C}\right)$

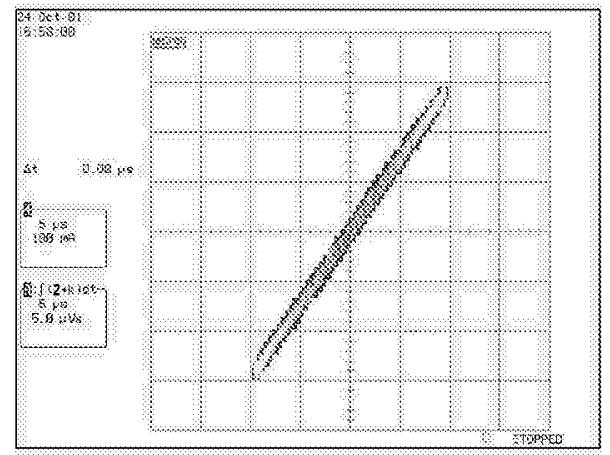

$\mathrm{KMC}\left(-180^{\circ} \mathrm{C}\right)$

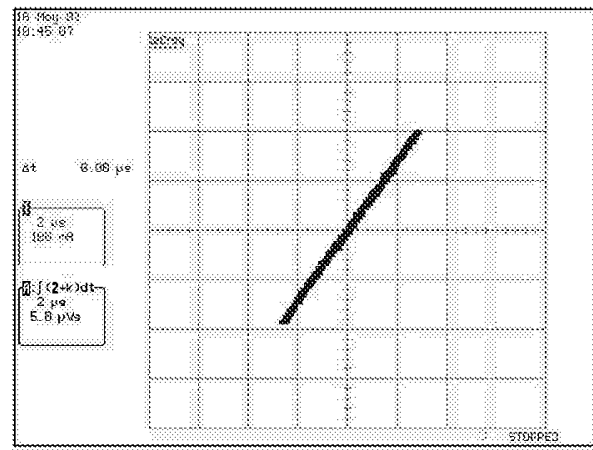

HFC $(-180 \circ)$

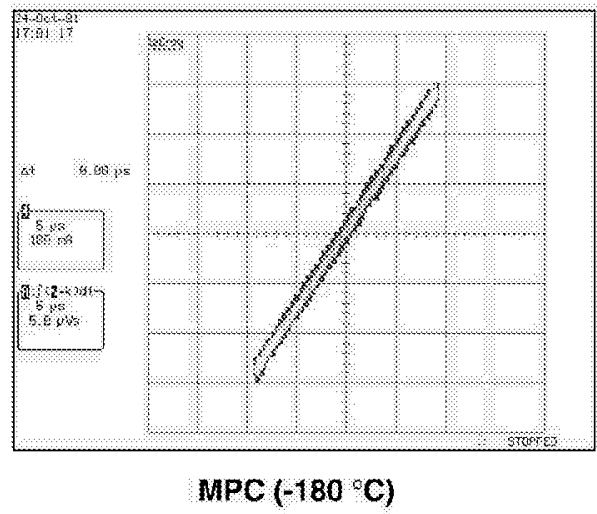

Figure 5. Effect of temperature on dynamic hysteresis characteristics. 


\section{\begin{tabular}{l|l|l} 
1. AGENCY USE ONLY (Leave blank) & 2. REPORT DATE & 3. REPORT TYPE AND DATES COVERED
\end{tabular}}

Performance of High-Frequency High-Flux Magnetic Cores

at Cryogenic Temperatures

6. A.BTHOR(S)

Scott S. Gerber, Ahmad Hammoud, Malik E. Elbuluk, and Richard L. Patterson

\section{PERFORMING ORGANIZATION NAME(S) AND ADDRESS(ES)}

National Aeronautics and Space Administration

John H. Glenn Research Center at Lewis Field

Cleveland, Ohio 44135-3191

\section{SPONSORING/MONITORING AGENCY NAME(S) AND ADDRESS(ES)}

National Aeronautics and Space Administration

Washington, DC 20546-0001
WU-297-60-10-00

\section{FUNDING NUMBERS}

\section{REPORT NUMBER}

E-13536

10. SPONSORING/MONITORING AGENCY REPORT NUMBER

NASA TM-2002-211836

IECEC-2002-20043

\section{SUPPLEMENTARY NOTES}

Prepared for the 37th Intersociety Energy Conversion Engineering Conference sponsored by the Institute of Electrical and Electronics Engineers, Electron Devices Society, Washington, DC, July 28-August 2, 2002. Scott S. Gerber, ZIN Technologies, Inc., 3000 Aerospace Parkway, Brook Park, Ohio 44142; Ahmad Hammoud, QSS Group, Inc., Cleveland, Ohio 44135; Malik E. Elbuluk, University of Akron, Electrical Engineering Department, Akron, Ohio 44325--3904; Richard L. Patterson, NASA Glenn Research Center. Responsible person, Richard L. Patterson, organization code 5480, 216-433-8166.

12a. DISTRIBUTION/AVAILABILITY STATEMENT 12b. DISTRIBUTION CODE

Unclassified-Unlimited

Subject Category: 33

Distribution: Nonstandard

Available electronically at mo/gitrs.scinasiagow

This publication is available from the NASA Center for Aerospace Information, 301-621-0390.

\section{ABSTRACT (Maximum 200 words)}

Three magnetic powder cores and one ferrite core, which are commonly used in inductor and transformer design for switch mode power supplies, were selected for investigation at cryogenic temperatures. The powder cores are Molypermalloy Core (MPC), High Flux Core (HFC), and Kool Mu Core (KMC). The performance of four inductors utilizing these cores has been evaluated as a function of temperature from $20^{\circ} \mathrm{C}$ to $-180^{\circ} \mathrm{C}$. All cores were wound with the same wire type and gauge to obtain equal values of inductance at room temperature. Each inductor was evaluated in terms of its inductance, quality $(\mathrm{Q})$ factor, resistance, and dynamic hysteresis characteristics (B-H loop) as a function of temperature and frequency. Both sinusoidal and square wave excitations were used in these investigations. Measured data obtained on the inductance showed that both the MPC and the HFC cores maintain a constant inductance value, whereas with the $\mathrm{KMC}$ and ferrite core hold a steady value in inductance with frequency but decrease as temperature is decreased. All cores exhibited dependency, with varying degrees, in their quality factor and resistance on test frequency and temperature. Except for the ferrite, all cores exhibited good stability in the investigated properties with temperature as well as frequency. Details of the experimental procedures and test results are presented and discussed in the paper.

14. SUBJECT TERMS

\begin{tabular}{|l|l|}
\hline & $\begin{array}{c}\text { 15. NUMBER OF PAGES } \\
13\end{array}$ \\
\cline { 2 - 2 } & 16. PRICE CODE \\
\hline $\begin{array}{l}\text { 19. SECURIY CLASSIFICATION } \\
\text { OF ABSTRACT } \\
\text { Unclassified }\end{array}$ & 20. LIMITATION OF ABSTRACT \\
\hline
\end{tabular}

Inductors; Magnetics; Cryogenics; Power supplies 